\title{
Characteristics of the non-carcass components of steers fed different sources of dietary carbohydrates
}

\section{Características dos componentes não integrantes da carcaça de novilhos alimentados com diferentes fontes de carboidratos na dieta}

\author{
Leandro da Silva Freitas ${ }^{1 *}$; Ivan Luiz Brondani²; Ana Paula Machado Martini ${ }^{3}$; \\ Alisson Marian Callegaro 3 ; Perla Cordeiro de Paula Colvero ${ }^{3}$; Patrícia Alessandra \\ Menegussi Metz Donicht ${ }^{4}$; Paulo Santana Pacheco ${ }^{2}$; Leonel da Silva Rodrigues; \\ Amanda Farias de Moura $^{5}$; Camille Carijo Domingues ${ }^{5}$
}

\begin{abstract}
We evaluated the characteristics of the non-carcass components of 24 steers (Charolais $\times$ Nelore) fed different carbohydrate sources (ground corn, soybean hulls, or wheat bran) in the diet. The animals were $353.2 \mathrm{~kg}$ and 22 months of age at early termination, and had been fed forage consisting of sorghum silage at a forage:concentrate ratio of 40.2:59.8. The carbohydrate sources had no effect on the weights of the carcass, vital organs, and blood. The absolute weights of the intestines and rumen fat were higher $(\mathrm{P}<0.05)$ in animals fed corn than in those fed soybean hulls or wheat bran $(10.87 \mathrm{vs} .8 .89$ and $8.87 \mathrm{~kg}$ and 5.26 vs. 4.12 and $3.64 \mathrm{~kg}$, respectively). The same pattern was observed when these organs weights were adjusted for empty body weight. The weight of the omasum was highest $(\mathrm{P}<0.05)$ in the wheat bran-fed animals (6.02 vs. 4.70 and $5.49 \mathrm{~kg}$ in the corn- and soybean hull-fed animals, respectively). Animals fed soybean hulls had a higher absolute weight of kidney fat $(1.6 \mathrm{~kg})$ than steers receiving wheat bran $(1.06 \mathrm{~kg})$ or corn $(0.79 \mathrm{~kg})$. Wheat bran gave the highest leg weight compared with corn and soybean hulls (2.46 vs. 2.22 and $2.23 \mathrm{~kg}$ per $100 \mathrm{~kg}$ of empty body weight, respectively).

Key words: Corn. Empty body. Internal fat. Soybean hulls. Vital organs. Wheat bran.
\end{abstract}

\section{Resumo}

Foram avaliadas as características dos componentes não integrantes da carcaça de 24 novilhos castrados, cruza Charolês x Nelore, alimentados com milho, casca de soja ou farelo de trigo como fontes de carboidratos na dieta. Os animais no início da terminação estavam com 353,2 kg e 22 meses de idade e foram alimentados com dieta com relação volumoso:concentrado de 40,2:59,8 sendo o volumoso constituído de silagem de sorgo. Não houve efeito das fontes de carboidratos sobre os rendimentos de carcaça e o peso dos órgãos vitais e de sangue. Os pesos absolutos dos intestinos $(10,87 ; 8,89$ e 8,87

1 Prof. Dr., Instituto Federal Farroupilha, IFFar, Campus São Vicente do Sul, RS, Brasil. E-mail: leandro.freitas@iffarroupilha. edu.br

2 Profs. Drs., Universidade Federal de Santa Maria, UFSM, Santa Maria, RS, Brasil. E-mail: ilbrondani@gmail.com; paulosantanapacheco@hotmail.com

3 Zootecnistas, Drs., UFSM, Santa Maria, RS, Brasil. E-mail: anapaulamartini@zootecnista.com.br; mcalisson@yahoo.com.br; perla.zoot@gmail.com

${ }^{4}$ Prof $^{a}$ Dr $^{\mathrm{a}}$, Instituto Federal Farroupilha, IFFar, Campus Alegrete, RS, Brasil. E-mail: patricia.donicht@iffarroupilha.edu.br

5 Discentes, Curso de Doutorado, Programa de Pós-Graduação em Zootecnia, UFSM, Santa Maria, RS, Brasil. E-mail: rodrigues_ leonel@hotmail.com; af.moura@hotmail.com; camidomingues1@gmail.com

* Author for correspondence 
$\mathrm{kg})$ e da gordura ruminal $(5,26 ; 4,12$ e $3,64 \mathrm{~kg})$ foram mais altos $(\mathrm{P}<0,05)$ nos animais alimentados com milho em relação aos alimentados com casca de soja ou farelo de trigo, respectivamente. Mesmo comportamento ocorreu quando estes órgãos foram ajustados ao peso de corpo vazio. O peso de omaso foi maior $(\mathrm{P}<0,05)$ para a dieta com farelo de trigo em relação ao milho $(6,02$ versus $4,70 \mathrm{~kg})$, os quais não deferiram da casca de soja $(5,49 \mathrm{~kg})$. Animais alimentados com casca de soja apresentaram maior peso absoluto de gordura renal $(1,6 \mathrm{~kg})$ em relação aos novilhos que receberam farelo de trigo $(1,06 \mathrm{~kg})$ ou milho $(0,79 \mathrm{~kg})$. O farelo de trigo proporcionou maior peso de patas em comparação ao milho e a casca de soja, com médias de 2,22; 2,23 e 2,46 kg 100 $\mathrm{kg}^{-1}$ de corpo vazio, respectivamente.

Palavras-chave: Casca de soja. Corpo vazio. Farelo de trigo. Gordura interna. Milho. Órgãos vitais.

\section{Introduction}

In recent years, Brazilian research has placed more emphasis on studies of the non-carcass components of cattle. This is because the non-carcass components, along with the digesta, have a direct influence on the carcass weight and yield. Besides that, differences in the relative size of the organs may be associated with differences in the maintenance requirements of the animals (THOMPSON et al., 1983; CATON; DHUYVETTER, 1997; JORGE et al., 1999). In addition, the non-carcass components of cattle are important sources of revenue for the meat processing company (RESTLE et al., 2005) and play a key role in other segments of the economy. Kuss et al. (2007) highlighted that the leather and vital organs (heart, liver, kidneys, and intestines) are among the components of higher value for the meat processing company, representing 10-15\% and $2-4 \%$ of the value of the carcass, respectively. As for the weight of the leather, studies have shown that the slaughter weight (SW) (RESTLE et al., 2005) and the genetic group (SIGNORETTI et al., 1999; PACHECO et al., 2005) of the animals influence this characteristic.

With regard to the viscera, internal organs, and visceral fat, Di Marco et al. (2007) stated that these non-carcass components differ according to the animal's breed, age, and feeding level. Studies have shown that an increase in the level of concentrate in the diet tends to increase the size of the internal organs while reducing that of the gastrointestinal tract (GIT) (FERREIRA et al., 2000; VÉRAS et al., 2001). However, the increase in energy consumption usually leads to greater body fat deposition in the animal (ROBELIN; GEAY, 1984). In relation to the size and content of the GIT, some researchers have indicated that the filling of this organ is proportional to the size of the food particles and inversely proportional to the digestibility of the forage (MACITELLI et al., 2005; MENEZES et al., 2011), and may represent about $5-25 \%$ of the live weight (LW) of the animal (ROHR; DAENICKE, 1984).

Most of the cattle diets in Brazil are formulated with corn to supply the energy demands of the animals. However, in order to reduce feed costs, other agroindustrial co-products can be used as alternative sources of energy, such as soybean hulls (SH) and wheat bran (WB). However, the fermentation patterns of these carbohydrates differ from those of corn starch and may provide better ruminal $\mathrm{pH}$ conditions and a higher proportion of acetic acid:propionic acid, resulting in better conditions for fiber digestion (BEN-GHEDALIA et al., 1989; DALKE et al., 1997; IPHARRAGUERRE; CLARK, 2003). This leads to interference with the synthesis of metabolites produced in the different organs, which is reflected in the development of the non-carcass components.

This present study was done with the objective of quantifying the non-carcass components of steers fed different sources of carbohydrates.

\section{Materials and Methods}

This study was carried out at the Cattle Breeding Laboratory of the Department of Animal Science of the Federal University of Santa Maria, located 
in the municipality of Santa Maria, Rio Grande do Sul, Brazil. Twenty-four castrated steers of approximately 22 months of age and initial body weight of $353.2 \pm 10.6 \mathrm{~kg}$ were used. The steers were a result of Charolais $(\mathrm{Ch}) \times$ Nelore $(\mathrm{Ne})$ crosses, belonging to the following genetic groups: $11 / 16 \mathrm{Ch}$ $5 / 16 \mathrm{Ne}, 11 / 16 \mathrm{Ne} 5 / 16 \mathrm{Ch}, 21 / 32 \mathrm{Ch} 11 / 32 \mathrm{Ne}$, and $21 / 32 \mathrm{Ne} 11 / 32 \mathrm{Ch}$. The steers were distributed into three groups $(n=8)$ that were respectively fed diets containing one of the following carbohydrate sources: ground corn (GC), SH, or WB. The feeding period was 46,51 , and 63 days for the $\mathrm{GC}, \mathrm{SH}$, and
WB groups, respectively. The feeding was divided into two meals, given daily at 08:00 and 14:00. Every day before the first meal, the leftovers from the previous day were collected and weighed to adjust the amount supplied and to record the dry matter intake. The leftovers were kept at between $5 \%$ and $10 \%$ of the total meal given. The diets (Table 1) were calculated according to guidelines of the National Research Council (NRC, 2000), aiming at an average weight gain of $1.2 \mathrm{~kg}$ per animal, using a forage:concentrate ratio of 40.2:59.8.

Table 1. Proportion of ingredients and bromatological composition of the experimental diets.

\begin{tabular}{lccc}
\hline Ingredient (\%) & \multicolumn{3}{c}{ Sources of carbohydrates } \\
\cline { 2 - 4 } & GC & SH & WB \\
\hline Sorghum silage & 40.2 & 40.2 & 40.2 \\
Soybean meal & 11.2 & 7.9 & 1.2 \\
Ground corn & 44.41 & - & - \\
Soybean hulls & - & 48.55 & - \\
Wheat bran & - & - & 524.9 \\
Soybean sludge & 2.99 & 2.99 & 2.99 \\
Calcitic limestone & 0.09 & 0.006 & 2.81 \\
Sodium chloride & 0.3 & 0.3 & 0.3 \\
\hline Bromatological composition (\%) & & & 63.73 \\
DM & 63.62 & 63.92 & 7.86 \\
MM & 5.62 & 6.52 & 13.10 \\
CP & 12.66 & 12.87 & 4.87 \\
EE & 4.29 & 4.07 & 51.03 \\
NDF & 35.86 & 60.75 & 26.70 \\
NFC & 44.48 & 21.14 & 0.29 \\
DE Mcal/kg of DM & 0.33 & 0.30 & \\
\hline
\end{tabular}

$\mathrm{GC}=$ ground corn; $\mathrm{SH}=$ soybean hulls; $\mathrm{WB}=$ wheat bran; $\mathrm{DM}=$ dry matter; $\mathrm{MM}=$ mineral matter; $\mathrm{CP}=$ crude protein; $\mathrm{EE}=$ ether extract; $\mathrm{NDF}=$ neutral detergent fiber; $\mathrm{NFC}=$ non-fibrous carbohydrates; $\mathrm{DE}=$ digestible energy.

Once the animals had reached the predetermined mean weight $(430 \mathrm{~kg})$, they were subjected to a solid and liquid fasting period of 14 hours, and then weighed (SW) and transported to a commercial meat processing facility. The slaughter of the animals took place according to the Regulation of
Industrial and Sanitary Inspection of Products of Animal Origin, following the normal flow of the meat processing facility.

At the time of slaughter, the following parts of the animal's body were weighed individually: external organs (head, ears, horns when present, legs, tail 
tip, and leather); vital organs (heart, lungs, liver, kidneys, and spleen); components of the empty GIT (rumen-reticulum, omasum, abomasum, and small and large intestines); internal fats (heart, inguinal, renal, rumen-reticulum, abomasum, intestines, and trim); and blood.

Before being sent to the cooler, the two halfcarcasses were identified and weighed to determine the warm carcass weight. After 24 hours of chilling in a cooler at $1{ }^{\circ} \mathrm{C}$, the carcasses were weighed again to obtain the cold carcass weight. The empty body weight (EBW) was obtained by subtracting the sum of the weights of the warm carcass, blood, external components, vital organs, empty GIT, and internal fats. From the SW, EBW, and warm carcass and cold carcass weights, the warm and cold carcass yields were determined in relation to the EBW. The contents of the GIT (CGIT) weight was calculated as the difference between the weight of the full digestive tract contents and that of the empty digestive tract.

The experiment was carried out in a randomized block design with three treatments and eight samples per treatment, with the animal being the experimental unit. The block criterion used was the racial predominance of the animals. The data were submitted to analysis of variance (ANOVA) and the $\mathrm{F}$ test at the 5\% significance level, using PROC GLM. When differences between means were detected, these were compared using the least significant difference test as well as the Pearson correlation test. The mathematical model adopted in the ANOVA was as follows: $\gamma_{i j k}=\mu+\tau_{i}+\beta_{j}+\tau \beta_{i j}$ $+\varepsilon_{i j k}$, where $\gamma_{i j k}=$ dependent variables; $\mu=$ overall mean of all observations; $\tau_{i}=$ effect of the $i$ th level of the carbohydrate source, where $1=\mathrm{GC}, 2=$ $\mathrm{SH}$, and $3=\mathrm{WB} ; \beta_{j}=$ effect of the $j$ th block for racial predominance; $\tau \beta_{i j}=$ effect of the interaction between the $i$ th level of the carbohydrate source and the $j$ th block for racial predominance (error $a$ ); and $\varepsilon_{i j k}=$ residual random error (error $\left.b\right), \operatorname{NID}\left(0, \sigma^{2}\right)$.

The data were tested for normality using the Shapiro-Wilk test. All statistical analyses were performed with SAS software (Statistical Analysis System, version 9.2).

\section{Results and Discussion}

The EBW and the cold and warm carcass yields adjusted to the EBW were not influenced by the carbohydrate sources in the diet (Table 2), which was explained by the similarity of the SWs and by the CGIT weights among the three experimental groups (Table 3). In the present study, the correlation between the EBW and SW was $0.96(\mathrm{P}<0.0001)$, and that between the EBW and the CGIT weight was $0.58(\mathrm{P}=0.0032)$. A number of studies have shown that when the SW and the fasting period are predetermined, the EBW (PAZDIORA et al., 2009; MENEZES et al., 2011) and the carcass yield (MISSIO et al., 2009) do not seem to change. On the other hand, when evaluating the inclusion of different concentrate levels $(20 \%, 40 \%, 60 \%$, and $80 \%$ ) in the diet of cattle slaughtered at 450 $\mathrm{kg}$, Silva et al. (2002) verified an increase in the carcass yield relative to the EBW and attributed this to the decrease of the CGIT with the inclusion of the concentrate. According to Geay (1975), as cited by Jorge et al. (1997), the carcass yields are more consistent when determined in relation to the EBW, since the CGIT weight may vary between $10 \%$ and $20 \%$ of the LW because of the feed system. In the present study, there was a negative association between the cold carcass yield adjusted to the EBW and the CGIT weight $(\mathrm{r}=-0.47, \mathrm{P}=0.0190)$. 
Table 2. Physical characteristics of the carcass and non-carcass components of steers fed different carbohydrate sources in the diet.

\begin{tabular}{|c|c|c|c|c|c|}
\hline \multirow{2}{*}{ Characteristic } & \multicolumn{3}{|c|}{ Carbohydrate sources } & \multirow{2}{*}{$\mathrm{CV}$} & \multirow{2}{*}{ P-Value } \\
\hline & GC & SH & WB & & \\
\hline Slaughter weight & 429.81 & 433.18 & 430.46 & 7.51 & 0.9761 \\
\hline Empty body weight & 370.31 & 380.23 & 373.15 & 6.61 & 0.7173 \\
\hline $\mathrm{EBW} / \mathrm{SW}^{*}$ & 0.86 & 0.88 & 0.87 & 1.69 & 0.1126 \\
\hline WCY, kg 100 kg EBW-1 & 66.08 & 66.64 & 66.17 & 2.59 & 0.7870 \\
\hline CCY, kg $100 \mathrm{~kg} \mathrm{EBW}^{-1}$ & 64.72 & 65.08 & 64.71 & 2.59 & 0.8827 \\
\hline Blood, kg & 12.75 & 13.97 & 14.19 & 11.46 & 0.1745 \\
\hline Blood, kg 100 kg EBW-1 & 3.44 & 3.68 & 3.79 & 8.47 & 0.0925 \\
\hline
\end{tabular}

$\mathrm{GC}=$ ground corn; $\mathrm{SH}=$ soybean hulls; $\mathrm{WB}=$ wheat bran; $\mathrm{WCY}=$ warm carcass yield; $\mathrm{CCY}=$ cold carcass yield $\mathrm{CV}=$ coefficient of variation (\%). * Values are given as absolute weights and weights relative to $100 \mathrm{~kg}$ of EBW (kg $100 \mathrm{~kg}$ EBW-1).

Table 3. Absolute weights and weights relative to $100 \mathrm{~kg}$ of empty body weight $\left(\mathrm{kg} 100 \mathrm{~kg} \mathrm{EBW}^{-1}\right)$ of the components of the gastrointestinal tract (GIT) of steers fed different carbohydrates in the diet.

\begin{tabular}{lccccc}
\hline \multirow{2}{*}{ Characteristic } & \multicolumn{3}{c}{ Carbohydrate sources } & \multirow{2}{*}{ CV } & \multirow{2}{*}{ P-Value } \\
\cline { 2 - 4 } & GC & SH & WB & & \\
\hline Rumen-reticulum, kg & 6.51 & 6.71 & 6.64 & 9.86 & 0.8063 \\
Rumen-reticulum, kg 100 kg EBW-1 & 1.76 & 1.77 & 1.78 & 6.96 & 0.9320 \\
Omasum, kg & $4.70^{\mathrm{B}}$ & $5.49^{\mathrm{AB}}$ & $6.02^{\mathrm{A}}$ & 16.93 & 0.0343 \\
Omasum, kg 100 kg EBW-1 & $1.27^{\mathrm{B}}$ & $1.44^{\mathrm{AB}}$ & $1.62^{\mathrm{A}}$ & 16.78 & 0.0342 \\
Abomasum, kg & 1.46 & 1.24 & 1.28 & 21.84 & 0.3029 \\
Abomasum, kg 100 kg EBW & 0.40 & 0.33 & 0.34 & 25.20 & 0.2724 \\
Intestines, kg & $10.87^{\mathrm{A}}$ & $8.89^{\mathrm{B}}$ & $8.87^{\mathrm{B}}$ & 16.84 & 0.0263 \\
Intestines, kg 100 kg EBW-1 & $2.94^{\mathrm{A}}$ & $2.33^{\mathrm{B}}$ & $2.31^{\mathrm{B}}$ & 14.69 & 0.0049 \\
GIT, kg & 23.54 & 22.34 & 22.61 & 11.59 & 0.6462 \\
GIT, kg 100 kg EBW-1 & 6.36 & 5.86 & 6.05 & 10.04 & 0.2855 \\
CGIT, kg & 46.71 & 49.11 & 56.37 & 17.64 & 0.1193 \\
CGIT, kg 100 kg EBW & 12.60 & 12.88 & 15.04 & 14.51 & 0.0505 \\
\hline
\end{tabular}

$\mathrm{GC}=$ ground corn; $\mathrm{SH}=$ soybean hulls; $\mathrm{WB}=$ wheat bran; CGIT $=$ contents of the gastrointestinal tract; $\mathrm{CV}=$ coefficient of variation (\%).

Averages in the same row followed by different letters are significantly different $(\mathrm{P}<0.05)$ by the least significant difference test.

According to the NRC (1996), the relationship between the EBW and the final LW is calculated according to the following equation: $\mathrm{EBW}=$ $0.981 \mathrm{LW}$ in fasting. The EBW/SW ratios of the animals in the present study were similar among the treatments, with an average value of 0.87 . This corroborated the results of Owens et al. (1995), who used several regression equations to estimate the
EBW from the final body weight, obtaining EBWs in the range from 0.85 to 0.95 of the body weight.

Menezes et al. (2011) observed a higher EBW/ SW ratio in Devon steers finished in temperate pastures $(0.85)$ than in steers finished in tropical pastures (0.82). Peripolli et al. (2013) also observed a higher EBW/SW ratio in Hereford, Brangus, and Brahman cattle finished in a grazing system (0.93) 
or in confinement (0.93). These studies showed that when animals are fed diets containing fiber of low digestibility, higher filling in the digestive tract occurs and consequently a lower EBW yield is obtained. This situation represents a lower economic return for the producer, since the higher the weight of the digestive tract, the lower the carcass yield will be, which was not observed in the present study.

The blood weights, expressed in absolute value and relative to the EBW, did not differ with the different carbohydrate sources, with averages of $13.64 \mathrm{~kg}$ and $3.64 \mathrm{~kg} 100 \mathrm{~kg} \mathrm{EBW}^{-1}$ (Table 2). In absolute values, these results are higher than those observed by Menezes et al. (2011), who studied the finishing of slaughtered steers (average 380 $\mathrm{kg}$ ) in confinement, in a temperate pasture, and in a tropical pasture, and verified a blood weight of $9.56,8.87$, and $6.84 \mathrm{~kg}$ in those finishing conditions, respectively. Some studies have shown that the variation in blood weight follows the variations in the weights of the vital organs and the empty digestive tract, since it follows the variations in the metabolic rate of the animals (PACHECO et al.,
2005; KUSS et al., 2007). According to Kuss et al. (2007), the greater the deposition of tissues, the greater is the contribution of blood that is necessary for the transport of nutrients. In our present study, the blood weight correlated positively with the weights of all the vital organs $(r=0.67, P=0.0003)$, the empty digestive tract $(\mathrm{r}=0.47, \mathrm{P}=0.0220)$, and the group of external organs $(\mathrm{r}=0.46, \mathrm{P}=0.0232)$.

There was no effect $(\mathrm{P}>0.05)$ of the carbohydrate sources on the heart, lung, liver, kidney, and spleen weights (expressed in absolute values and relative to the EBW), the average absolute values of which were $1.19,5.40,5.46,0.77$, and $1.15 \mathrm{~kg}$, respectively (Table 4). The work conducted by Perón et al. (1993) emphasized that the heart and lung maintain their integrity because they have priority in the use of nutrients and are hardly influenced by the level of feeding. As for the kidneys and spleen, they have a lower priority than the heart and lungs in nutrient use when the animals experience a more pronounced growth of adipose and muscular tissue (PERÓN et al., 1993).

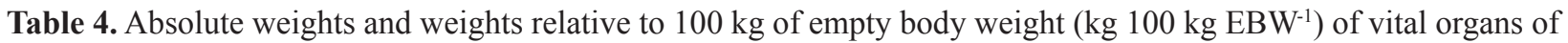
steers fed different carbohydrates in the diet.

\begin{tabular}{|c|c|c|c|c|c|}
\hline \multirow{2}{*}{ Characteristic } & \multicolumn{3}{|c|}{ Carbohydrate sources } & \multirow{2}{*}{$\mathrm{CV}$} & \multirow{2}{*}{ P-Value } \\
\hline & GC & SH & WB & & \\
\hline Heart, kg & 1.19 & 1.22 & 1.17 & 10.31 & 0.7022 \\
\hline Heart, kg $100 \mathrm{~kg} \mathrm{EBW}^{-1}$ & 0.32 & 0.32 & 0.31 & 8.36 & 0.7400 \\
\hline Lung, kg & 5.21 & 5.53 & 5.45 & 8.95 & 0.4090 \\
\hline Lung, kg $100 \mathrm{~kg} \mathrm{EBW}^{-1}$ & 1,41 & 1.45 & 1.46 & 7.21 & 0.5422 \\
\hline Liver, $\mathrm{kg}$ & 5.32 & 5.60 & 5.47 & 10.91 & 0.6427 \\
\hline Liver, kg $100 \mathrm{~kg} \mathrm{EBW}^{-1}$ & 1.43 & 1.47 & 1.46 & 7.19 & 0.7117 \\
\hline Kidneys, $\mathrm{kg}$ & 0.72 & 0.79 & 0.81 & 9.19 & 0.0667 \\
\hline Kidneys, kg $100 \mathrm{~kg} \mathrm{EBW}^{-1}$ & 0.19 & 0.21 & 0.22 & 8.23 & 0.0750 \\
\hline Spleen, kg & 1.12 & 1.19 & 1.14 & 19.69 & 0.8353 \\
\hline Spleen, kg $100 \mathrm{~kg} \mathrm{EBW}^{-1}$ & 0.30 & 0.31 & 0.30 & 18.95 & 0.9232 \\
\hline $\mathrm{GVO}, \mathrm{kg}$ & 13.56 & 14.34 & 14.04 & 8.06 & 0.4083 \\
\hline GVO, kg 100 kg EBW ${ }^{-1}$ & 3.66 & 3.77 & 3.76 & 4.83 & 0.4069 \\
\hline
\end{tabular}

$\mathrm{GC}=$ ground corn; $\mathrm{SH}=$ soybean hulls; $\mathrm{WB}=$ wheat bran; $\mathrm{GVO}=$ group of vital organs; $\mathrm{CV}=$ coefficient of variation $(\%)$. 
A series of studies (DROUILLARD et al., 1991; OWENS et al., 1993; FERREL; JENKINS, 1998) have indicated that among the vital organs, the liver responds the most to changes in food intake and the energy levels of the diet, as it participates in the metabolism of nutrients and, together with an increase in the size of the internal organs (FOX et al., 1992), responds in part to the greater requirements of the animals. Other studies have found that the liver size of the animal responded quickly to changes in food intake, presenting a linear development in response to an increase in metabolizable energy consumption (RICHMOND et al., 1988; JOHNSON et al., 1990). Jorge et al. (1999) compared the liver weights of steers slaughtered at the start of the experiment (lighter) with those of animals submitted to food restriction or fed at will and slaughtered with a higher weight, and found that the liver weight was lower in the animals subjected to food restriction.

Alves Filho et al. (2016) studied the partial replacement of corn silage with sunflower silage and found a higher relative liver weight with the silage inclusion at the level of $66 \%$. Ferreira et al. (2000) and Véras et al. (2001) found that the increase in the level of concentrate in the diet also influenced the development of the liver. On the other hand, Peripolli et al. (2013) observed higher liver weights in steers finished on grazing compared with steers finished in confinement with a forage:concentrate ratio of 60:40. Menezes et al. (2011) found a higher liver weight in animals finished in a temperate pasture $\left(1.58 \mathrm{~kg} 100 \mathrm{~kg} \mathrm{EBW}^{-1}\right)$ relative to that in animals finished in a tropical pasture $\left(1.25 \mathrm{~kg} 100 \mathrm{~kg} \mathrm{EBW}^{-}\right.$ $\left.{ }^{1}\right)$ and in confinement $\left(1.37 \mathrm{~kg} 100 \mathrm{~kg} \mathrm{EBW}^{-1}\right)$ and attributed this difference to the high crude-protein content in the temperate pasture.

As shown in Table 4, the weight of the group of vital organs was not different among the treatments, a pattern that was expected owing to the fact that there was no variation in the absolute and relative weights of the vital organs. However, other studies have shown that among the internal organs, the liver affects variations in the weights of the group of vital organs the most (RESTLE et al., 2005; MENEZES et al., 2011). In the present study, the internal organs did not influence the warm carcass yield when adjusted to $100 \mathrm{~kg}$ of EBW. On the other hand, for the lung, the absolute weight and the relative weight at $100 \mathrm{~kg}$ of EBW presented negative correlations with the warm carcass yield adjusted to $100 \mathrm{~kg}$ of EBW ( $\mathrm{r}=-0.48, \mathrm{P}=0.0164$ and $\mathrm{r}=-0.60, \mathrm{P}=$ 0.0017 , respectively).

The steers fed on WB presented higher absolute and relative omasum weights than those fed on GC or $\mathrm{SH}$, with these latter two diets presenting similar omasum results (Table 3). Missio et al. (2013), when studying Purunã cattle slaughtered at different weights, observed that the absolute weight of the omasum increased linearly with increase of the SW. Similarly, Jones et al. (1985) found higher omasum weights for animals fed diets based on forage (50\% corn silage $+50 \%$ alfalfa hay) than for animals fed diets based on concentrate (30\% corn silage $+70 \%$ GC). Van Soest (1994) commented that the omasum promotes water absorption and selects the material that enters the abomasum, retaining the more fibrous portion. The same author also stated that diets with high levels of concentrate cause involution of the omasum. In our present study, the GC diet presented a lower neutral detergent fiber (NDF) content than that in diets containing SH or WB (Table 1).

Silva et al. (2002) observed that the rumenreticulum and omasum weights were lower in diets with higher concentrate levels, due to the lower weight of the CGIT in such diets. Although not significant, the CGIT weight from the GC diet was $19.36 \%$ lower than that from the WB diet when adjusted to the EBW (Table 3). A higher CGIT weight is related to a higher consumption of nutrients and, consequently, the higher contribution of the nutrients, since they actively participate in the processes of digestion and absorption (PERÓN et al., 1993). 
Table 3 shows that the absolute intestinal weight of steers fed the GC diet was $22.4 \%$ higher than that of animals fed the SH or WB diets. This difference for the GC treatment was also maintained when the weight of the intestines was adjusted to $100 \mathrm{~kg}$ of EBW. The increase in intestinal size may be related to a higher intestinal metabolic activity, due to the higher non-fibrous carbohydrate content present in the GC diet (Table 1). According to Kozloski (2009), when the diets of ruminants consist of a high proportion of cereals (i.e., mainly corn or sorghum), significant amounts of starch can pass through the rumen without being fermented and are digested in the intestines. Peripolli et al. (2013) associated significant changes in the size of the intestines to compensatory gain effects, a behavior not evidenced in our present study.

The rumen-reticulum and abomasum compartments, expressed in the different weight forms, did not differ according to the different carbohydrate sources, and presented mean absolute weights of 6.62 and $1.33 \mathrm{~kg}$, respectively. According to Drouillard et al. (1991), the viscera vary in weight according to the proportion of energy consumed. Corroborating this statement, Missio et al. (2009) evaluated the inclusion of different concentrate levels $(22 \%, 40 \%, 50 \%, 59 \%$, and $79 \%$ ) in the finishing of crossbred Charolais $\times$ Nelore bulls and found similar weights for the rumen, abomasum, and intestinal compartments. Macitelli et al. (2005) observed a higher rumenreticulum weight in animals fed sugarcane silage than in those fed corn silage and Brachiaria brizantha pasture, attributing this increase to the larger particle size of sugarcane silage relative to the other forages, because the NDF content was lower in the sugarcane diet. Other studies found that the variation in the abomasum weight was mainly associated with the nutritional level (SIGNORETTI et al., 1999; GESUALDI JÚNIOR et al., 2001). This organ participates actively in the digestion of nutrients, and its participation may be higher or lower depending on the levels of concentrate in the animal diet (FERREL et al., 1976).

The absolute and relative weights of the GIT and CGIT were not influenced by the carbohydrate sources (Table 3), probably because of the same forage source and the same forage:concentrate ratio that were used for all the treatments. Studies have shown that an increase in the level of concentrate in the diet usually results in a reduction in the size and of the CGIT (FERREIRA et al., 2000; VÉRAS et al., 2001). Other studies indicated that the GIT filling is proportional to the size of the food particles and inversely proportional to the digestibility of the forage (ROHR; DAENICKE, 1984; MACITELLI et al., 2005). According to Gesualdi Júnior et al. (2001), the high forage:concentrate ratio of the diets used in the finishing of cattle in Brazil is another factor that contributes to the increase of the CGIT weight, when adjusted to the EBW.

Rohr and Daenicke (1984) commented that the CGIT weight represents about $5-25 \%$ of the LW, and associated this variation with factors such as the breed, weight, physiological state, type of feed, and the fasting time to which the animals are subjected. The present experiment verified that the CGIT weight showed correlations with the absolute weight of the empty rumen-reticulum $(r=0.67, \mathrm{P}=$ $0.0003)$ and with the daily weight gain $(r=-0.44, P$ $=0.0299)$ and was not significantly correlated with the digestible energy content $(r=-0.38, P=0.0678)$.

With regard to the accumulation of internal fats, Table 5 shows that the absolute weight of inguinal fat was higher for diets with GC or SH than for those with WB. However, when adjusted to the EBW, the GC diet presented a higher inguinal fat weight relative to the other treatments. Table 5 also shows that the rumen fat, expressed in absolute weight and adjusted to the EBW, was higher in the GCfed animals than in steers treated with $\mathrm{SH}$ or WB in the diet. This higher accumulation of inguinal and ruminal fats in the GC diet was possibly because of the diet's higher energy content (Table 1). The results of the present study are consistent with the 
reports of Silveira et al. (2013), who found a higher total visceral fat weight in steers fed with $50 \%$ and $65 \%$ of concentrate in the diet, and of Missio et al. (2009), who observed that animals fed with $79 \%$ of concentrate in the diet had a higher proportion of internal fat than those fed with $22 \%$ of concentrate.

Missio et al. (2009) observed that the deposition of rumen fat increased as the proportion of concentrate in the diet was increased. The same authors verified that the rumen fat correlated with the energy consumption of the $\operatorname{diet}(\mathrm{r}=0.83, \mathrm{P}<$ 0.0001 ). In our present study, the weights of the inguinal fat and of the rumen adjusted to the EBW correlated positively with the energy content of the diet, with $\mathrm{r}=0.68(\mathrm{P}=0.0003)$ and $\mathrm{r}=0.60(\mathrm{P}=$ $0.0019)$, respectively. According to Thompson et al. (1983), a higher proportion of visceral fat results in higher energy requirements for maintenance, due to the greater metabolic activity of the internal adipose tissue relative to that of the peripheral one. Besides that, the accumulated visceral fat becomes a burden, since it does not add any weight to the carcass but affects the efficiency of the animal in converting the consumed food, making its accumulation inevitable when the animal advances to the finishing phase (DI MARCO, 1998).

Table 5. Absolute weights and weights relative to $100 \mathrm{~kg}$ of empty body weight $\left(\mathrm{kg} 100 \mathrm{~kg} \mathrm{EBW}^{-1}\right)$ of different types of internal fat of steers fed different sources of carbohydrates in the diet.

\begin{tabular}{lccccc}
\hline \multirow{2}{*}{ Characteristic } & \multicolumn{3}{c}{ Carbohydrate sources } & \multirow{2}{*}{ CV } & \multirow{2}{*}{ P-Value } \\
\cline { 2 - 4 } & GC & SH & WB & & 0.15 \\
Heart, kg & 0.18 & 0.19 & 0.15 & 35.04 & 0.3839 \\
Heart, kg 100 kg EBW-1 & 0.05 & 0.05 & 0.04 & 33.25 & 0.3764 \\
Inguinal, kg & $2.74^{\mathrm{A}}$ & $2.37^{\mathrm{A}}$ & $1.88^{\mathrm{B}}$ & 18.90 & 0.0048 \\
Inguinal, kg 100 kg EBW-1 & $0.74^{\mathrm{A}}$ & $0.62^{\mathrm{B}}$ & $0.50^{\mathrm{C}}$ & 15.94 & 0.0008 \\
Kidneys, kg & $0.79^{\mathrm{B}}$ & $1.60^{\mathrm{A}}$ & $1.06^{\mathrm{B}}$ & 29.42 & 0.0004 \\
Kidneys, kg 100 kg EBW-1 & $0.21^{\mathrm{B}}$ & $0.42^{\mathrm{A}}$ & $0.28^{\mathrm{B}}$ & 29.47 & 0.0006 \\
Rumen, kg & $5.26^{\mathrm{A}}$ & $4.12^{\mathrm{B}}$ & $3.64^{\mathrm{B}}$ & 24.19 & 0.0215 \\
Rumen, kg 100 kg EBW-1 & $1.42^{\mathrm{A}}$ & $1.08^{\mathrm{B}}$ & $0.97^{\mathrm{B}}$ & 21.78 & 0.0074 \\
Abomasum, kg & 1.37 & 1.56 & 1.61 & 22.07 & 0.3422 \\
Abomasum, kg 100 kg EBW-1 & 0.37 & 0.41 & 0.43 & 22.99 & 0.4074 \\
Intestines, kg & 7.79 & 9.41 & 7.92 & 21.82 & 0.1785 \\
Intestines, kg 100 kg EBW-1 & 2.12 & 2.47 & 2.12 & 20.85 & 0.2529 \\
Trim, \% & 1.35 & 1.38 & 1.10 & 26.67 & 0.2357 \\
Trim, kg 100 kg EBW-1 & 0.36 & 0.36 & 0.29 & 23.70 & 0.1893 \\
Total fat, kg & 19.47 & 20.61 & 17.37 & 15.56 & 0.1261 \\
Total fat, kg 100 kg EBW-1 & 5.27 & 5.42 & 4.64 & 13.62 & 0.0980 \\
\hline
\end{tabular}

$\mathrm{GC}=$ ground corn; $\mathrm{SH}=$ soybean hulls; $\mathrm{WB}=$ wheat bran; $\mathrm{CV}=$ coefficient of variation (\%).

Averages in the same row followed by different letters are significantly different $(\mathrm{P}<0.05)$ by the least significant difference test.

The renal fat weight, in the different forms in which it was expressed, was higher in the animals that received $\mathrm{SH}$ in the diet than in those fed GC or WB (Table 5). A possible explanation for this is the higher molar ratio of acetic acid:propionic acid in the SH-containing diet. In a large literature review, Ipharraguerre and Clark (2003) reported that diets containing $\mathrm{SH}$ showed a constant increase 
in the ruminal ratio of acetic acid:propionic acid compared with grain-based diets. The change in this ratio interferes directly with the fat deposition sites, because whereas acetic acid is deposited directly in the adipose tissue, propionic acid is initially converted into glucose by the liver and then converted into glycerol and finally deposited in the adipose tissue; that is, propionic acid has a slower and less efficient conversion route (KOZLOSKI, 2009). Vaz et al. (2007) attributed the small numerical difference of $2.1 \%$ in the amount of fat in the carcass in favor of the animals finished in ryegrass pasture (relative to the steers finished in confinement) to the higher acetic acid:propionic acid molar ratio in the pasture diet. According to Luchiari Filho (2000), the various sites of fat deposition tend to take a fixed proportion in relation to the total fats, where renal and pelvic fats are the first to be deposited during growth, followed by intermuscular fat, subcutaneous fat, and finally intramuscular fat. When adjusted to the EBW, the renal fat weight showed a positive correlation with the NDF content $(r=0.69, \mathrm{P}=0.0002)$ and a negative correlation with the energy content of the $\operatorname{diet}(r=-0.41, P=0.0482)$.

The remaining fat deposition sites and the total fat weight were not influenced by the carbohydrate sources (Table 5), with the heart, abomasum, intestines, and trim presenting mean absolute fat weights of $0.17,1.51,8.37$, and $1.28 \mathrm{~kg}$, respectively. These fats represented approximately $0.88 \%, 7.88 \%, 43.7 \%$, and $6.7 \%$ of the total fats (average $19.15 \mathrm{~kg}$ ), respectively. There was a negative correlation between the total fat weight and the EBW $(r=-0.53, P=0.0122)$.

The head, legs, and leather (also called the hard residue or hard drop) represent $15-17 \%$ of the animal's weight (DI MARCO et al., 2007). In the present study, the mean weights of these organs combined were 14.97, 14.44, and $15.39 \mathrm{~kg} 100$ $\mathrm{kg} \mathrm{EBW}^{-1}$, respectively, for the $\mathrm{GC}, \mathrm{SH}$, and $\mathrm{WB}$ treatments (Table 6).

The lower the weight of these components, the greater the carcass yield will be. Table 6 shows that the absolute weight of the legs did not differ among the treatments, but when adjusted to the EBW, the leg weight of the WB-fed animals was verified to be $10.5 \%$ higher on average than that of the GCor SH-fed steers. This difference may be associated with the longer feeding period of the animals in confinement in order to reach the pre-stipulated SW (430 kg), which was 46, 51, and 63 days for the $\mathrm{GC}, \mathrm{SH}$, and WB diets, respectively. Missio et al. (2009) verified that the weight of the legs expressed relative to the EBW increased with the increase of concentrate in the diet, and associated the early growth of the bone tissue and the reduction of the age of slaughter with the increase of the concentrate.

Table 6. Absolute weights and weights relative to $100 \mathrm{~kg}$ of empty body weight ( $\left.\mathrm{kg} 100 \mathrm{~kg} \mathrm{EBW}^{-1}\right)$ of external components of steers fed different carbohydrate sources in the diet.

\begin{tabular}{|c|c|c|c|c|c|}
\hline \multirow{2}{*}{ Characteristic } & \multicolumn{3}{|c|}{ Diet } & \multirow{2}{*}{$\mathrm{CV}$} & \multirow{2}{*}{ P-Value } \\
\hline & $\mathrm{GC}$ & $\mathrm{SH}$ & WB & & \\
\hline Head, kg & 13.51 & 13.22 & 13.71 & 6.36 & 0.5324 \\
\hline Head, kg 100 kg EBW-1 & 3.66 & 3.48 & 3.68 & 5.90 & 0.1523 \\
\hline Ears, $\mathrm{kg}$ & 0.57 & 0.56 & 0.53 & 26.65 & 0.8716 \\
\hline Ears, kg $100 \mathrm{~kg} \mathrm{EBW}^{-1}$ & 0.15 & 0.15 & 0.14 & 22.09 & 0.8450 \\
\hline Legs, $\mathrm{kg}$ & 8.26 & 8.47 & 9.17 & 10.04 & 0.1277 \\
\hline Legs, kg 100 kg EBW-1 & $2.22^{\mathrm{B}}$ & $2.23^{\mathrm{B}}$ & $2.46^{\mathrm{A}}$ & 6.56 & 0.0100 \\
\hline $\mathrm{TT}, \mathrm{kg}$ & 0.16 & 0.14 & 0.10 & 41.45 & 0.1103 \\
\hline
\end{tabular}


continuation

\begin{tabular}{lccccc} 
TT, kg $100 \mathrm{~kg} \mathrm{EBW}^{-1}$ & 0.04 & 0.04 & 0.03 & 39.63 & 0.0880 \\
Leather, kg & 33.64 & 33.26 & 34.49 & 13.64 & 0.8686 \\
Leather, kg $100 \mathrm{~kg} \mathrm{EBW}^{-1}$ & 9.09 & 8.73 & 9.25 & 12.08 & 0.6302 \\
$\mathrm{TEC}, \mathrm{kg}$ & 56.21 & 55.65 & 58.07 & 9.23 & 0.6460 \\
$\mathrm{TEC}, \mathrm{kg} 100 \mathrm{~kg} \mathrm{EBW}$ & -1 & 14.62 & 15.58 & 7.02 & 0.2285 \\
\hline GC = ground corn; SH = soybean hulls; WB = wheat bran; TT = tail tip; TEC = total of external components; CV= coefficient of \\
variation (\%). \\
Averages in the same row followed by different letters are significantly different $(\mathrm{P}<0.05)$ by the least significant difference test.
\end{tabular}

The absolute weight and the weight relative to $100 \mathrm{~kg}$ of EBW of the head, ears, and tail tip were not influenced by the carbohydrate sources. This disagreed with the results of Menezes et al. (2011), who observed that the head and tail tip weights varied with the feed system, where animals finished in temperate and tropical pastures presented higher head weights than those finished in confinement, with values of 4.95, 4.87, and $4.64 \mathrm{~kg} 100 \mathrm{~kg} \mathrm{EBW}^{-}$ ${ }^{1}$, respectively. As for the tail tip, the animals in confinement presented a weight similar to those finished in a temperate pasture, but higher than those finished in a tropical pasture. Jorge and Fontes (2001) found allometric coefficients lower than 1 for the head, leg, and leather weights adjusted to the EBW, demonstrating that the development of these components occurs at the younger age of the animal and does not accompany the increase of the EBW.

With regard to the leather, from the commercial point of view, this external component is the most valued by the meat processing company and can represent an equivalent value of $10-15 \%$ of the price paid for the carcass (KUSS et al., 2008). Table 6 shows that the carbohydrate sources did not influence the weight of the leather, with mean values of $33.8 \mathrm{~kg}$ and $9.02 \mathrm{~kg} 100 \mathrm{~kg} \mathrm{EBW}^{-1}$ among the three dietary treatments. The values of the leather weight adjusted to the EBW were similar to those reported by Di Marco et al. (2007), who stated that the bovine leather weight represents, on average, $9-10 \%$ of the EBW. The same authors also commented that the leather weight is lower in animals fed with concentrate than in animals fed with forage. The leather can be influenced by the weight (RESTLE et al., 2005), age of slaughter (PACHECO et al., 2005), and breed of the animal (DI MARCO et al., 2007). In the present study, the leather weight adjusted to the EBW showed a negative correlation with the warm carcass yield ( $\mathrm{r}$ $=-0.67, \mathrm{P}=0.0004)$ and consequently with the cold carcass yield $(\mathrm{r}=-0.66, \mathrm{P}=0.0004)$. It has been shown that the carcass yield is influenced not only by the digestive tract, as ratified by some authors, but also by the participation of other body tissues, mainly the external components. In this present study, the weight of the total external components adjusted to the EBW was negatively correlated with the warm carcass yield $(\mathrm{r}=-0.73, \mathrm{P}<0.0001)$.

\section{Conclusions}

Alternative sources of carbohydrates, such as $\mathrm{SH}$ or WB, can be used to feed steers in the finishing phase, as they do not alter the warm and cold carcass yields or the the weight of the vital organs and blood. Animals fed GC presented a lower omasum weight and higher intestine and inguinal and ruminal fat weights. On the other hand, SH provided a larger deposit of renal fat, whereas WB produced a higher weight of the legs.

\section{References}

ALVES FILHO, D. C.; BARCELLOS, J. O. J.; ZAGO, D.; SARTORI, E. D.; ANTUNES, K. K.; ANDRADE, N. T. de. Características da carcaça de novilhos terminados em confinamento com inclusão parcial na dieta de silagem 
de girassol. Archivos Latinoamericanos de Producción Animal, Maracaibo, v. 24, n. 3, p. 139-148, 2016.

BEN-GHEDALIA, D.; YOSEF, E.; MIRON, J.; EST, Y. The effects of starch and pectin-rich diets on quantitative aspects of digestion in sheep. Animal Feed Science and Technology, Amsterdam, v. 24, n. 3-4, p. 289-298, 1989. DOI: 10.1016/0377-8401(89)90150-8

CATON, J. S.; DHUYVETTER, D. V. Influence of energy supplementation on grazing ruminants: requirements and responses. Journal of Animal Science, Champaign, v. 75, n. 2, p. $533-542$, 1997. DOI: $10.2527 / 1997.752533 x$

DALKE, B. S.; SONON JUNIOR, R. N.; YOUNG, M. A.; HUCK, G. L.; KREIKEMEIER, K. K.; BOLSEN, $\mathrm{K}$. K. Wheat middlings in high-concentrate diets: feedlot performance, carcass characteristics, nutrient digestibilities, passage rates, and ruminal metabolism in finishing steers. Journal of Animal Science, Champaign, v. 75 , n. 9, p. 2561-2566, 1997. DOI: $10.2527 / 1997.7592561 \mathrm{x}$

DI MARCO, O. N. Crecimiento de vacunos para carne. Mar del Plata: Balcarce, 1998. 246 p.

DI MARCO, O. N.; BARCELLOS, O. J.; COSTA, E. C. Crescimento de bovinos de corte. Porto Alegre: UFRGS, 2007. $276 \mathrm{p}$.

DROUILLARD, J. S.; KLOPFENSTEIN, T. J.; BRITTON, R. A.; BAUER, M. L.; GRAMLICH, S. M.; WESTER, T. J.; FERRELL, C. L. Growth, body composition and visceral organ mass and metabolism in lambs during and after metabolizable protein or net energy restrictions. Journal of Animal Science, Champaign, v. 69 , n. 8 , p. $3257-3375,1991$. DOI: $10.2527 / 1991.6983357 x$

FERREIRA, M. A.; VALADARES FILHO, S. D. C.; MUNIZ, E. B.; VERAS, A. S. C. Características das carcaças, biometria do trato gastrintestinal, tamanho dos órgãos internos e conteúdo gastrintestinal de bovinos F1 Simental $\times$ Nelore alimentados com dietas contendo vários níveis de concentrado. Revista Brasileira de Zootecnia, Viçosa, MG, v. 29, n. 4, p. 1174-1182, 2000.

FERREL, C. L.; GARRET, W. N.; HINMAN, N. Estimation of body composition in pregnant and nonpregnant heifers. Journal of Animal Science, Champaign, v. 42 , n. 5 , p. $1158-1166,1976$.

FERRELL, C. L.; JENKINS, T. G. Body composition and energy utilization by steers of diverse genotypes fed a high-concentrate diet during the finishing period: I. Angus, Belgian Blue, Hereford, and Piedmontese Sires. Journal of Animal Science, Champaign, v. 76, n. 2, p. 647-657, 1998. DOI: $10.2527 / 1998.762637 \mathrm{x}$
FOX, D. G.; SNIFFEN, C. J.; O'CONNOR, J. D.; RUSSELL, J. B.; VAN SOEST, P. J. A net carbohydrate and protein system for evaluating cattle diets: III. Cattle requirements and diet adequacy. Journal of Animal Science, Champaign, v. 70, n. 11, p. 3578-3596, 1992. DOI: $10.2527 / 1992.70113578 x$

GEAY, Y. Live weight measurement. In: EEC SEMINAR ON CRITERIA AND METHODS FOR ASSESSMENT OF CARCASS AND MEAT CHARACTERISTICS IN BEEF PRODUCTION EXPERIMENTS, 1975, Zeist. Proceedings... Zeist, 1975. p. 35-42.

GESUALDI JÚNIOR, A.; VELOSO, C. M.; PAULINO, M. F.; VALADARES FILHO, S. V.; GESUALDI, A. C. L. S.; CECON, P. R. Níveis de concentrado na dieta de bovinos F1 Limousin $\times$ Nelore: peso de órgãos internos e trato digestivo. Revista Brasileira de Zootecnia, Viçosa, MG, v. 30, n. 6, p. 1866-1871, 2001. DOI: $10.1590 /$ S1516-35982001000700028

IPHARRAGUERRE, I. R.; CLARK, J. H. Soyhulls as an alternative feed for lactating dairy cows: a review. Journal of Dairy Science, Champaign,v. 86, n. 4, p. 10521073, 2003. DOI: 10.3168/jds.S0022-0302(03)73689-3

JOHNSON, D. E.; JOHNSON, K. A.; BALDWIN, R. L. Changes in liver and gastrointestinal tract energy demands in response to physiological workload in ruminants. Journal of Nutrition, Bethesda, v. 120, n. 6, p. 649-655, 1990. DOI: 10.1093/jn/120.6.649

JONES, S. D. M.; ROMPALA, R. E.; JEREMIAH, L. E. Growth and composition of the empty body in steers of different maturity types fed concentrate or forage diets. Journal of Animal Science, Champaign, v. 60, n. 2, p. 427-433, 1985. DOI: $10.2527 /$ jas 1985.602427x

JORGE, A. M.; FONTES, C. A. A. Desenvolvimento relativo das partes do corpo de zebuínos de quatro raças. Ciência Rural, Santa Maria, v. 31, n. 5, p. 857-861, 2001.

JORGE, A. M.; FONTES, C. A. A.; SOARES, J. E.; FREITAS, J. D.; RODRIGUES, L. R.; QUEIROZ, A. C.; RESENDE, F. D. Características quantitativas da carcaça de bovinos e bubalinos, abatidos em diferentes estádios de maturidade. Revista Brasileira de Zootecnia, Viçosa, MG, v. 26, n. 5, p. 1039-1047, 1997.

JORGE, A. M.; FONTES, C. A. D. A.; PAULINO, M. F.; GOMES JÚNIOR, P. Tamanho relativo dos órgãos internos de zebuínos sob alimentação restrita e ad libitum. Revista Brasileira de Zootecnia, Viçosa, MG, v. 28 , n. 2 , p. $374-380,1999$. DOI: $10.1590 / \mathrm{S} 1516-$ 35981999000200022

KOZLOSKI, G. V. Bioquímica dos ruminantes. 2. ed. Santa Maria: Universidade Federal de Santa Maria, 2009. $214 \mathrm{p}$. 
KUSS, F.; BARCELLOS, J. O. J.; LÓPEZ, J.; RESTLE, J.; MOLETTA, J. L.; PAULA, M. C. D. Componentes não-integrantes da carcaça de novilhos não-castrados ou castrados em confinamento e abatidos aos 16 ou 26 meses de idade. Revista Brasileira de Zootecnia, Viçosa, MG, v. 37, n. 10, p. 1829-1836, 2008.

KUSS, F.; RESTLE, J.; BRONDANI, I. L.; PACHECO, P. S.; SILVEIRA, M. F.; PAZDIORA, R. D.; CEZIMBRA, I. M. Órgãos vitais e trato gastrintestinal de vacas de descarte mestiças Charolês $\times$ Nelore abatidas com pesos distintos. Revista Brasileira de Zootecnia, Viçosa, MG, v. 36, n. 2, p. 421-429, 2007.

LUCHIARI FILHO, A. Pecuária da carne bovina. São Paulo: A Luchiari Filho, 2000. 134 p.

MACITELLI, F.; BERCHIELLI, T. T.; SILVEIRA, R. N. D.; ANDRADE, P. D.; LOPES, A. D.; SATO, K. J.; BARBOSA, J. C. Biometria da carcaça e peso de vísceras e de órgãos internos de bovinos mestiços alimentados com diferentes volumosos e fontes proteicas. Revista Brasileira de Zootecnia, Viçosa, MG, v. 34, n. 5, p. 17511762, 2005.

MENEZES, L. F. G.; BRONDANI, I. L.; RESTLE, J.; ALVES FILHO, D. C.; CALLEGARO, A. M.; WEISE, M. Características dos componentes não integrantes da carcaça de novilhos superjovens da raça Devon, terminados em diferentes sistemas de alimentação. Arquivo Brasileiro de Medicina Veterinária e Zootecnia, Belo Horizonte, v. 63, n. 2, p. 372-381, 2011. DOI: 10.1590/S0102-09352011000200015

MISSIO, R. L.; BRONDANI, I. L.; RESTLE, J.; SILVA, J. H. S.; SILVEIRA, M. F.; SILVA, V. S. Partes não-integrantes da carcaça de tourinhos alimentados com diferentes níveis de concentrado na dieta. Revista Brasileira de Zootecnia, Viçosa, MG, v. 38, n. 5, p. 906915, 2009.

MISSIO, R. L.; RESTLE, J.; MOLETTA, J. L.; KUSS, F.; NEIVA, J. N. M.; MIOTTO, F. R. C.; PRADO, I. N.; ELEJALDE, D. A. G.; PEROTTO, D. Componentes do corpo vazio de vacas da raça Purunã abatidas com pesos distintos. Semina: Ciências Agrárias, Londrina, v. 34, n. 2, p. 883-894, 2013. DOI: $10.5433 / 1679-0359.2013 v 34 n 2 p 883$

NATIONAL RESEARCH COUNCIL - NRC. Nutrient requirements of beef cattle. $7^{\text {th }} \mathrm{ed}$. Washington: National Academy Press, 1996. 242 p.

NATIONAL RESEARCH COUNCIL - NRC. Nutrient requirements of beef cattle. $7^{\text {th }}$ rev. ed. Update 2000. Washington: National Academy Press, 2000. 232 p.

OWENS, F. N.; DUBESKI, P.; HANSON, C. F. Factors that alter the growth and development of ruminants.
Journal of Animal Science, Champaign, v. 71, n. 11, p. 3138-3150, 1993. DOI: 10.2527/1993.71113138x

OWENS, F. N.; GILL, D. R.; SECRIST, D. S.; COLEMAN, S. W. Review of some aspects of growth and development of feedlot cattle. Journal of Animal Science, Champaign, v. 73, n. 10, p. 3152-3172, 1995. DOI: $10.2527 / 1995.73103152 x$

PACHECO, P. S.; RESTLE, J.; SILVA, J. H. S.; ARBOITTE, M. Z.; ALVES FILHO, D. C.; FREITAS, A. K. D.; ROSA, J. R. P.; PÁDUA, J. T. Características das partes do corpo não-integrantes da carcaça de novilhos jovens e superjovens de diferentes grupos genéticos. Revista Brasileira de Zootecnia, Viçosa, MG, v. 34, n. 5, p. 1678-1690, 2005.

PAZDIORA, R. D.; SANTOS, A. P.; BRONDANI, I. L.; RESTLE, J.; ARBOITTE, M. Z.; CEZIMBRA, I. M. Componentes não-integrantes da carcaça de novilhos jovens e superjovens terminados em confinamento. Acta Scientiarum. Animal Sciences, Maringá, v. 30, n. 1, p. 95101, 2009. DOI: $10.4025 /$ actascianimsci.v31i1.542

PERIPOLLI, V.; BARCELLOS, J. O. J.; OLMEDO, D. A. O.; LAMPERT, V. D. N.; VELHO, M. M. S. Componentes não-integrantes da carcaça de bovinos de três grupos genéticos terminados em confinamento ou pastejo rotacionado com suplementação. Revista Brasileira de Saúde e Produção Animal, Salvador, v. 14, n. 1, p. 209-223, 2013.

PERÓN, A. J.; FONTES, C. A. A.; LANA, R. P.; SILVA, D. J.; QUEIROZ, A. C.; PAULINO, M. Tamanho dos órgãos internos e distribuição da gordura corporal em novilhos de cinco grupos genéticos, submetidos à alimentação restrita e ad libitum. Revista Brasileira de Zootecnia, Viçosa, MG, v. 22, n. 5, p. 813-819, 1993.

RESTLE, J.; MENEZES, L. D.; ARBOITTE, M. Z.; PASCOAL, L. L.; PACHECO, P. S.; PÁDUA, J. T. Características das partes não-integrantes da carcaça de novilhos $5 / 8$ Nelore $3 / 8$ Charolês abatidos em três estádios de desenvolvimento. Revista Brasileira de Zootecnia, Viçosa, MG, v. 34, n. 4, p. 1339-1348, 2005.

RICHMOND, C. E.; LUNT, D. K.; GREENE, L. W.; BYERS, F. M. Effects of dietary restriction and subsequent re-alimentation on liver mass in growing/ finishing beef steers. Nutrition Reports International, v. 38, n. 3, p. 501-509, 1988.

ROBELIN, J.; GEAY, Y. Body composition of cattle as affected by physiological status, breed, sex and diet. In: GILCHRIST, F. M. C.; MACKIE, R. I. (Ed.). Herbage nutrition in the subtropics and tropics. Johannesburg: Science Press, 1984. p. 525-547. 
ROHR, K.; DAENICKE, R. Nutritional effects on the distribution of live weight as gastrointestinal tract fill and tissue components in growing cattle. Journal of Animal Science, Champaign, v. 58, n. 3, p. 753-765, 1984. DOI: $10.2527 /$ jas $1984.583753 \mathrm{x}$

SIGNORETTI, R. D.; SILVA, J. D.; VALADARES FILHO, S. D. C.; PEREIRA, J. C.; ARAUJO, G. D.; CECON, P. R.; QUEIROZ, A. C.; MUNIZ, E. B. Crescimento, conversão alimentar e rendimento de carcaça de bezerros da raça holandesa alimentados com dietas contendo diferentes níveis de volumoso. Revista Brasileira de Zootecnia, Viçosa, MG, v. 28, n. 1, p. 185194, 1999.

SILVA, F. F.; VALADARES FILHO, S. D. C.; ÍTAVO, L. C. V.; VELOSO, C. M.; PAULINO, M. F.; VALADARES, R. F. D.; CECON, P. R.; SILVA, P. A.; GALVÃO, R. M. Consumo, desempenho, características de carcaça e biometria do trato gastrintestinal e dos órgãos internos de novilhos Nelore recebendo dietas com diferentes níveis de concentrado e proteína. Revista Brasileira de Zootecnia, Viçosa, MG, v. 31, n. 4, p. 1849-1864, 2002. DOI: $10.1590 / \mathrm{S} 1516-35982002000600029$

SILVEIRA, M. F.; ALVES FILHO, D. C.; MISSIO, R. L.; METZ, P. A. M.; RESTEL, J.; SEGABINAZZI, L. R.; CALlegaro, A. M.; JONER, G. Componentes externos e gordura interna de novilhos Charolês ou Nelore alimentados com diferentes proporções de concentrado. Semina: Ciências Agrárias, Londrina, v. 34, n. 2, p. 863874, 2013. DOI: 10.5433/1679-0359.2013v34n2p863

THOMPSON, W. R.; MEISKE, J. C.; GOODRICH, R. D.; RUST, J. R.; BYERS, F. M. Influence of body composition on energy requirements of beef cows during winter. Journal of Animal Science, Champaign, v. 56, n. 5, p. 1241-1251, 1983. DOI: 10.2527/jas 1983.5651241x

VAN SOEST, P. J. Nutritional ecology of the ruminant. 2. ed. Ithaca: Cornell University Press, 1994. 476 p.

VAZ, F. N.; RESTLE, J.; PADUA, J. T.; METZ, P. A. M.; MOLETTA, J. L.; FERNANDES, J. J. R. Qualidade da carcaça e da carne de novilhos abatidos com pesos similares, terminados em diferentes sistemas de alimentação. Ciência Animal Brasileira, Goiânia, v. 8, n. 1, p. 31-40, 2007.

VÉRAS, A. S. C.; VALADARES, F. S. D. C.; FERNANDO, C. D. S. J.; FONSECA, P. M.; CECON, P. R.; VALADARES, R. F. D.; FERREIRA, M. A.; FONTES, C. M. S. Efeito do nível de concentrado sobre o peso dos órgãos internos e do conteúdo gastrintestinal de bovinos Nelore não-castrados. Revista Brasileira de Zootecnia, Viçosa, MG, v. 30, p. 1120-1126, 2001. Suplemento 1. 